\title{
Study of Senior Management in Liquor Enterprise Training Mode Cheng-Chun LONG
}

\author{
School of Management, Sichuan University Of Science \& Engineering \\ Zigong, Sichuan, China. 643000 \\ long200725@126.com
}

Key words: liquor enterprise, senior management, training mode, research

\begin{abstract}
: the quality of the liquor business executives directly affects, and even determine the survival and development of the liquor business, so to strengthen the training of senior management is particularly important. This article puts forward the construction strategy of liquor enterprises senior management training from five aspects as classroom teaching training mode to the goal of enrich the management knowledge, practice training mode on the basis of action learning, concept training model to stimulate self-development of senior management, management skills development training mode to improve the leadership ability oriented, multi-channel training mode to improve the training effectiveness.
\end{abstract}

\section{Introduction}

Liquor enterprise senior management is decision makers and key enablers of a liquor business development strategies, and "Chinese liquor Golden Triangle" strategy makes higher quality and ability requirements to the regional liquor enterprise senior management also. Research found that the purpose of the liquor business to carry out a variety of training, in general, is to improve the attitude of executives, values, behavior, knowledge, quality, ability level. But the mode and methods of training is single. skills training takes a more mode of "send to separate training" and class teaching, supplemented by case analysis. Many liquor companies' systems on executive training are not well established and the training effects are uneven. Therefore, to strengthen the training of senior management and explore effective training model is particularly important to improve the quality of liquor business executives.

\section{Class Teaching Mode to the Goal of Enrich the Management Knowledge}

Liquor business executives, many of which are elected from the liquor professional and technical positions along with step by step growth. They are proficient in the knowledge and expertise of the liquor industry, but lack of modern management theory knowledge and technology. Class teaching also known for lectures refer to the process of passing information from expert to the target groups, can effectively make the audience understand the theories, concepts, procedures and other declarative data ${ }^{[1]}$. Classroom teaching style training, can make executives in a relatively short period of time, effective learning and increasing the management of knowledge. Moreover, the centralized training, also provides a platform for the exchanges of liquor business executives. For classroom teaching, the enterprises can choose to send executives to universities or research institutions to focus on learning, also can choose to invite train teachers to enterprises giving classes. But for executives at this level, give priority to "send out", namely choose some colleges and universities is the frontier of management theory research, as the counterpart of the training institutions for the management knowledge and skills. At the same time, classroom instruction training, can be supplemented by classroom discussion, case analysis, etc., in order to enhance the trainees and teachers, as well as the different communication of homes of trainees to inspired thinking, enhance the training effect. 


\section{Practice Training Mode on the Basis of Action Learning}

Action learning refers to the training mode that suppose a problem faced by a group or working team in a practical work and organize them to work together to solve and develop an action plan, and implement the program ${ }^{[2]}$. Management is a subject with strong practicality. Whether a senior manager can lead the local liquor business achieved good performance, not only lies in the appropriate management knowledge and skills, more is the proper management methods in management practice. Therefore, action learning training methods, which allows real management problem to be solved in class, can improve the management practice of senior management.

In the course of action learning, first, we should establish a learning team. Team members can be from different liquor companies, and should not hold the same point of view of identical members, better in different ideas. Second, to clarify the problem that the team faced of which the source is in the actual situation of each liquor enterprise management activities to enhance the pertinence. Third, team members give full play to creative thinking, to find the way to solve the problem, and develop an action plan after team discussion to plan implementation and improvement. Finally, extend the learning outcomes (i.e.: a problem solving strategy) to other new work environment, to explore the general principle and method of how to solve this kind of problem. Through the development of this kind of action learning as the basic training of management practices, can make the training activities and actual management activities closely linked, both trained executives to solve practical problems, and conducive to the cultivation of training the innovation and transformation of thinking, continuous innovation to solve problems of strategy to truly improve the management ability.

\section{Self-Development Concept Stimulation Training Mode for Senior Management}

The self-development of senior executives mainly includes self-cognition, self-learning, self-making and achieving goals, self-monitoring. It is an important way to stimulate the self-development of the top management of liquor enterprises. Large and medium sized liquor enterprises attach great importance to the construction of enterprise culture, especially the training of management personnel enterprise values. In fact, in this training of changing the employees' ideas and work attitude, should join the concept of management personnel development training.

"self-awareness" training allows senior management personnel to understand his character from management, psychology, behavioral science and other aspects to know their own strengths and weaknesses, to understand their behavior, understand their needs and ownership, clear their responsibility and contribution to the organization.

"self-learning" training allows senior management personnel to acknowledge learning theory, learning methods and strategies, learning organization and other aspects of knowledge training. Especially to instill "battery theory" and "stem cell theory, leading executives to study diligently, dares to innovate, do the constantly charging to continue to discharge the battery", and is not discharged and scrap dry battery, training senior managers of lifelong learning ability

"self-making and achieving the goal" theory attach importance to the method of target management., enable senior management to have a more profound understanding of the target management, understand that the goal of management is not only a way of enterprise performance management, but also a way of self-development of management personnel. The management objectives for self-planning, self-set goals, self-control, self-promotion goal reached, finally self-assessment, make oneself toward the established goal to development, culminating in the comprehensive quality and ability and work performance to achieve a qualitative leap.

"self-monitoring" training develop and improve the liquor business executives of self-monitoring. Robbins (S.P.Robbins) 1998 believes that self-monitoring is the ability of individuals to adjust their behavior according to the external situation factors ${ }^{[3]}$. High self-monitoring manager will be more flexible in his work, get more promotion opportunities, it is more likely to occupy the core position in the organization ${ }^{[4]}$. Because there are differences between individuals in self-monitoring, therefore, we should improve the self-monitoring ability of senior management. First train the senior management personne to eatablish self-monitoring consciousness through the concept 
training; then use "self-monitoring table" to evaluate self-monitoring ability of senior managers; and according to the score of the questionnaire to help executives understand which part need to be improved, then corresponding training along with senior executives’ own conscious.

\section{Management Skills Development Training Mode to Improve Leadership.}

Management skills development is a training program specifically for managers to adapt to changes in the organization's internal and external environment, and constantly improve their management skills and capabilities. Liquor enterprise's development and the benefit is more and more restricted by the management level of the senior management, and many practical management knowledge and ability need the enterprise to develop itself. In the process of the development of the senior management of the liquor business, a variety of training methods can be used:

The first category: evaluation center technology, including industry case analysis, document basket method, non-leading group discussion, role play, management games and other training methods. This training mainly to improve executives with planning and organizational skills, the analysis, decision-making ability, language expression ability, role grasp ability, interpersonal relationship processing ability, strain capacity, risk-taking ability.

The second category: development technology for management skills, mainly including leader matching training, leadership training, interpersonal relationship analysis training, sensitivity training, teamwork training, time management training and other methods. The training focuses on helping the liquor enterprise executives according to the specific environment choose different styles of leadership, make sure the scale allowing subordinates to participate in the decision-making, learn to analyze their specific ego state, improve insight on their own behavior and others, improve sensitivity and ability of environmental change and management performance, team work ability, also coordinate ability with the use of time.

Management skills development training in liquor enterprise should not limited trainees to existing executives, and it should be possible expanded to all middle and even at the grass-roots level management personnel, to improve the management skill level of the entire management team, for senior management personnel preparation and selection of foundation base. For some small liquor business with limited training funds can carry out management skill training for "multi step waterfall" mode, namely after received a training, a few outstanding senior management personnel can give a training to middle-level management of the enterprise staff as trainer, so that layers down, in order to enhance the popularity and the management level of management knowledge and skills.

\section{Multi-Channel Training Mode to Improve Training Effectiveness.}

Management skills development training in liquor enterprise more use classroom teaching style and sent the senior management to the well-known colleges and universities to receive training. Actually, there are many channels for the training, mainly including enterprise internal training, corporate training and exchange, institutions formal training, amateur learning or correspondence learning, management group activities, learning type organization construction, network training, expand training, adventure learning and so on. Liquor companies can choose different training channels and methods based on specific training programs for the purpose, content, teacher, trainee characteristics, time, location, funding and other actual situation. For example, in the "Chinese Liquor Golden Triangle Strategy" implementation process, the exchange training of liquor business in this region is more important. Liquor industry association can organize training activities of this channel. In addition, through the establishment of learning organization, encouraging managers use spare time to participate in the study by correspondence or short-term training, and organizing as long as on-line training and other flexible and diverse forms of training, not only can achieve the purpose of increase management knowledge, also can be in a certain extent, save cost of training, make the training time arrangement be more flexible, establish a wide range of learning atmosphere. Management group activities in internal training should combine the actual situation of enterprise 
work, and carry out and adjust the training on contenr, time and progress. Multi channel training can get better training effect.

\section{Conclusion}

The training of senior management of liquor enterprises is a systematic project. This paper puts forward the construction strategy of liquor enterprises senior management training, combining with the characters of liquor industry and "Chinese Liquor Golden Triangle Strategy" during the study process, from five aspects as classroom teaching training mode to the goal of enrich the management knowledge, practice training mode on the basis of action learning, concept training model to stimulate self-development of senior management, management skills development training mode to improve the leadership ability oriented, multi-channel training mode to improve the training effectiveness., and proposed liquor business senior management trainings, methods and strategies, in order to systematized, standardized training with pertinence and practicality, in order to achieve the purpose and effect of training.

\section{Acknowledgement}

The research work was supported by Sichuan province philosophy social sciences project funding: The study of liquor enterprise senior managers training mode based on the strategy of "Chinese liquor golden triangle”. NO. SC12BJ11

\section{References}

[1] Xu Fang. Training and development theory and technology [M]. Shanghai: Fudan University press, 2009:188.

[2] D.Doctlich and J.Noel,Active. Learning:How the World's Top Companies Are Recreating Their Leaders and Themselves(San Francisco:Jossey-Bass,1998).

[3] Stephen P Robbins. Organizational behavior (Tenth Edition) [M]. Beijing: Renmin University of China press, 2005: 110.

[4] M.Kilduff and D.V.Day,“Do Chameleons Get Ahead? The Effects of Self-Monitoring on Managerial Careers,”Academy of Management Journal,August 1994,pp.1047-1060;

and A.Mehra,M.Kilduff,and D.J.Brass,"The Social Networks of High and Low Self-Monitors:Implications for Workplace Performance,”Administrative Science Quarterly,March 2001,pp.121-146.

[5] Raymond A noe. Employee training and development (Third Edition) [M]. Beijing: Renmin University of China press, 2008. 